\title{
Validation of a Method To Quantify Copper and Other Metals in Olive Fruit by ETAAS. Application to the Residual Metal Control after Olive Tree Treatments with Different Copper Formulations
}

\author{
Maria Elisa Soares,${ }^{\dagger}$ José Alberto Pereira,,${ }^{\ddagger}$ AND \\ MARIA LOURDES BASTOS $*, \dagger$ \\ REQUIMTE/Serviço de Toxicologia, Faculdade de Farmácia, Universidade do Porto, \\ R. Aníbal Cunha 164, 4050-047 Porto, Portugal, and CIMO/ESAB, Quinta de Sta Apolónia, \\ Apartado 1172, 5301-855 Bragança, Portugal
}

\begin{abstract}
An electrothermal atomization atomic absorption spectrometry method was validated to quantify residues of copper, aluminum, cadmium, chromium, iron, lead, and nickel in olive fruit. The linearity ranges under the optimized conditions were $0.19-20.0,1.11-50.0,0.02-2.0,0.15-20.0,0.80-$ 20.0, 0.35-50.0, and $0.60-50.0 \mu \mathrm{g} / \mathrm{L}$, respectively. The limits of quantification were, expressed in nanograms per gram of dry weight, 12.6, 74.0, 1.34, 10.0, 53.4, 23.4, and 40.0, respectively. For all of the metals the precision of the instrumental method was $<6.3 \%$ and that of the analytical method was always $<10 \%$, except for aluminum, for which the precision was $12 \%$. The accuracy of the method was evaluated according to the standard additions method, the recoveries being $>90 \%$ for all of the added concentrations. An interference study was also carried out in a simulated matrix, and it was verified that the deviations of the expected values were $<6 \%$ for all of the metals. The method was applied to the monitoring of the residues of the referred metals in olive fruits collected from trees pulverized with three different copper formulations available on the market to control fungal diseases.
\end{abstract}

KEYWORDS: Method validation; atomic absorption spectrometry; metal residues; olive fruits; fungicide residues

\section{INTRODUCTION}

Olive fruits are mainly destined for the extraction of olive oil but are also consumed as table olives after ripening. Both products have to meet several quality parameters including heavy metal contents. Heavy metals can be present in olive fruits for two reasons: endogenous, depending on the mineral constitution of the soils where the olive trees are located, or exogenous, resulting from air pollution, contamination by phytochemical products, and technological processing. Besides the toxicological characteristics of these elements, the presence of transition metals in these fat matrices can negatively influence the organoleptic and nutritional properties as well as the shelf life of the products. For example, iron, copper, and nickel, which possess two or more valence states with a suitable redox potential, can act as pro-oxidants even at concentrations of $<0.1$ $\mu \mathrm{g} / \mathrm{g}(1,2)$.

Among several metals, copper is of great importance because formulations containing this element are largely used as fungicides to fight fungal diseases of olive trees. In fact, olive leaf spot is the most dangerous fungal disease for the olive tree

* Author to whom correspondence should be addressed (telephone + 351 222078989; fax + 351 222003977; e-mail mlbastos@ff.up.pt).

REQUIMTE.

$\doteqdot \mathrm{CIMO} / \mathrm{ESAB}$ in the Mediterranean Basin (3-5), and anthracnose is very damaging for olive fruits in various regions of southern Italy (6) and Portugal. To control these diseases, bait sprays are applied two times a year, one at the end of winter/beginning of spring and another at the beginning of autumn $(3,4)$. Copper oxychloride, copper sulfate, copper hydroxide, cuprous oxide, and zirame are registered and are currently used in olive groves in Portugal for the treatments of the diseases mentioned above $(7,8)$, and these copper products are authorized for use in organic agriculture (9). The autumn application coincides with the fruit maturation period and, in some cases, the harvest period begins at the first or second week of November, just a month or even less after the spray of copper products.

Copper is a transition metal that even in small concentrations is a very potent oxidation catalyst (10), can enter a redox reaction, and give rise to the lipid peroxidation phenomenon. Taking into account the high contents of lipids in olive fruit, their copper residues should be controlled to ascertain their influence in the final product quality.

The literature refers to methodologies for metal determination in olive oil $(10-15)$. However, to our knowledge only the validation of a method to quantify iron and manganese in table olives by flame atomic absorption spectrometry has been reported so far (16). The present work describes a validated electrothermal atomization atomic absorption spectrometry 
Table 1. Instrumental Conditions and Graphite Furnace Programs for Quantification of $\mathrm{Cu}, \mathrm{Al}, \mathrm{Cd}, \mathrm{Cr}, \mathrm{Fe}, \mathrm{Pb}$, and $\mathrm{Ni}$ in Olive Fruits Treated with Three Different Copper Formulations

\begin{tabular}{|c|c|c|c|c|c|c|c|}
\hline parameter & $\mathrm{Cu}$ & $\mathrm{Al}$ & $\mathrm{Cd}$ & $\mathrm{Cr}$ & $\mathrm{Fe}$ & $\mathrm{Pb}$ & $\mathrm{Ni}$ \\
\hline wavelength (nm) & 324.8 & 309.3 & 228.8 & 357.9 & 248.3 & 283.3 & 232.0 \\
\hline ashing temp $\left({ }^{\circ} \mathrm{C}\right)$ & 1100 & 1700 & 700 & 1600 & 1400 & 700 & 1300 \\
\hline atomization temp $\left({ }^{\circ} \mathrm{C}\right)$ & 2300 & 2500 & 1100 & 2500 & 2400 & 1800 & 2500 \\
\hline $\begin{array}{l}\text { injection vol of sample/ } \\
\text { modifier }(\mu \mathrm{L})^{a}\end{array}$ & & & & $15 / 10$ & & & \\
\hline inert gas & \multicolumn{7}{|c|}{ argon } \\
\hline flow rate $\left(\mathrm{mL} \mathrm{min}^{-1}\right)$ & \multirow{2}{*}{\multicolumn{7}{|c|}{300}} \\
\hline background correction & \multirow{2}{*}{\multicolumn{7}{|c|}{$\begin{array}{c}\text { deuterium arc } \\
\text { with integrated platform }\end{array}$}} \\
\hline HGA tubes & & & & & & & \\
\hline gas stop flow & \multicolumn{7}{|c|}{ atomization step } \\
\hline measurement mode & & & \multicolumn{5}{|c|}{ integrated absorbance } \\
\hline
\end{tabular}

${ }^{a}$ The autosampler was programmed to pipet sequentially $10 \mu \mathrm{L}$ of the modifier solution and $15 \mu \mathrm{L}$ of the digested sample/standard solution and dispense them together on the platform. For $\mathrm{Al}$ and $\mathrm{Fe}$ determination the chemical modifier was $0.01 \mathrm{mg}$ of $\mathrm{Mg}\left(\mathrm{NO}_{3}\right)_{2}$. For $\mathrm{Pb}, \mathrm{Cr}, \mathrm{Cd}$, and $\mathrm{Ni}$ the chemical modifier was $0.03 \mathrm{mg}$ of $\mathrm{Pd}\left(\mathrm{NO}_{3}\right)_{2}+0.02 \mathrm{mg}$ of $\mathrm{Mg}\left(\mathrm{NO}_{3}\right)_{2}$. Cu was evaluated without chemical modifier.

(ETAAS) method to quantify several metals in olive fruits with interest in toxicological, nutritional, and stability perspectives. This validated method was applied to the analysis of copper contents of olives collected in the most important olive fruits cultivar (cv. Cobrançosa) produced in the Trás-os-Montes region (northeastern Portugal), from olive trees treated with three currently used copper formulations for the control of fungal diseases. To accomplish this purpose, we collected olive fruits at five different times after the treatment. Copper residues were evaluated as well as aluminum, cadmium, chromium, iron, lead, and nickel in the collected olives, to verify the levels of contamination of the olive fruits.

\section{MATERIALS AND METHODS}

Reagents and Materials. All of the solutions were prepared with doubly deionized water and the chemicals used ( $\mathrm{HF}, \mathrm{HCl}, \mathrm{HNO}_{3}$, and $\mathrm{H}_{2} \mathrm{O}_{2}$ ) were of pro analysis grade (Merck).

Standard metal solutions were prepared daily from $1000 \mathrm{mg} \mathrm{L}^{-1}$ solutions (Spectrosol, $\mathrm{BDH}$ ) in $0.2 \% \mathrm{HNO}_{3}$ Suprapure grade (Merck).

Chemical modifiers, $1 \mathrm{~g} / \mathrm{L}$ of $\mathrm{Mg}\left(\mathrm{NO}_{3}\right)_{2}$ solution and $2 \mathrm{~g} / \mathrm{L}$ of $\mathrm{Mg}\left(\mathrm{NO}_{3}\right)_{2}+3 \mathrm{~g} / \mathrm{L}$ of $\mathrm{Pd}\left(\mathrm{NO}_{3}\right)_{2}$ solution, Suprapur grade from Merck, were prepared in $15 \%(\mathrm{v} / \mathrm{v})$ Suprapur nitric acid.

Decontamination of Material. To avoid contamination of the samples, all PTFE materials (Teflon vessels, pipets, micropipet tips, and autosampler cups) were immersed in freshly prepared $15 \% \mathrm{v} / \mathrm{v}$ pro analysis $\mathrm{HNO}_{3}$ (Merck) during $24 \mathrm{~h}$, then rinsed thoroughly with doubly deionized water, and dried in a dustfree area before use.

Apparatus. Metal quantifications were carried out in a Perkin-Elmer HGA-850 furnace installed in a model AAnalyst 300 spectrometer with deuterium arc background correction, equipped with an AS-800 autosampler and a HP Deskjet 920C. The analyses were performed using Perkin-Elmer HGA tubes with integrated platform.

The instrumental operating conditions and furnace programs for the determination of the elements are summarized in Table 1.

Sample Preparation. Wet Digestion Procedure. The olive fruits were washed with tap water, the stones were removed, and the pulp was cut into small portions with a plastic knife previously rinsed with $15 \% \mathrm{HNO}_{3}$ and doubly deionized water, packed in PVC decontaminated tubes, and dried in an oven at $60 \pm 2{ }^{\circ} \mathrm{C}$ for several days. The dried samples were reduced to powder in a Teflon container, and two digestion procedures were carried out.

Procedure A. Approximately $0.5 \mathrm{~g}$ of powdered sample was accurately weighed and transferred to a Teflon container which, after the addition of $1.5 \mathrm{~mL}$ of $\mathrm{HNO}_{3}+0.5 \mathrm{~mL}$ of $\mathrm{HCl}$ and $250 \mu \mathrm{L}$ of $\mathrm{H}_{2} \mathrm{O}_{2}$, was closed for digestion during $17 \mathrm{~h}$ in an oven thermostatically
Table 2. Principal Constituents of Olive Fruits ${ }^{a}$ Used To Prepare the Simulated Matrix Used in the Interference Studies

\begin{tabular}{lllr}
\hline $\begin{array}{c}\text { inorganic } \\
\text { constituent }\end{array}$ & $\begin{array}{c}\text { concn } \\
(\mathrm{g} / 100 \mathrm{~g})\end{array}$ & $\begin{array}{c}\text { organic } \\
\text { constituent }\end{array}$ & $\begin{array}{c}\text { concn } \\
(\mathrm{g} / 100 \mathrm{~g})\end{array}$ \\
\hline chloride & 3.5 & carbohydrate & 1.0 \\
calcium & 0.060 & fat & 15.0 \\
potassium & 0.085 & protein & 0.9 \\
sodium & 2.0 & celulose & 2.0 \\
phosphates & 0.015 & & \\
magnesium & 0.020 & & \\
iron & 0.010 & & \\
copper & 0.003 & &
\end{tabular}

a From ref 17.

controlled at $90 \pm 2{ }^{\circ} \mathrm{C}$. The digested solution was transferred to a decontaminated tube and diluted to $10 \mathrm{~mL}$ with doubly deionized water.

Procedure B. Approximately $0.5 \mathrm{~g}$ of powdered sample was accurately weighed and transferred to a Teflon container: step 1, 0.5 $\mathrm{mL}$ of $\mathrm{HF}$ and $2 \mathrm{~mL}$ of $\mathrm{HNO}_{3}$ were added to the sample and heated at $90 \pm 2{ }^{\circ} \mathrm{C}$ during $8 \mathrm{~h}$ to enable the volatilization of silicates; step 2, to this residue were added $1.5 \mathrm{~mL}$ of $\mathrm{HNO}_{3}+0.5 \mathrm{~mL} \mathrm{HCl}$ and $250 \mu \mathrm{L}$ of $\mathrm{H}_{2} \mathrm{O}_{2}$, and the Teflon container was closed for digestion during 17 $\mathrm{h}$ in a stove thermostatically controlled at $90 \pm 2{ }^{\circ} \mathrm{C}$. The digested solution was transferred to a decontaminated tube and diluted to 10 $\mathrm{mL}$ with doubly deionized water.

Method Validation. The analytical conditions for metal measurement were established by using the respective standard acid solutions and olive fruit digested sample solutions. Calibration against acidified standard solutions was performed, and the linear ranges were established for each element using working ranges from 0 to $2.0 \mu \mathrm{g} / \mathrm{L}$ for $\mathrm{Cd}$, from 0 to $20.0 \mu \mathrm{g} / \mathrm{L}$ for $\mathrm{Cu}, \mathrm{Cr}$, and $\mathrm{Fe}$, and from 0 to $50.0 \mu \mathrm{g} / \mathrm{L}$ for $\mathrm{Al}, \mathrm{Pb}$, and $\mathrm{Ni}$.

The limit of detection was calculated as $3 s / m$, where $s$ is the standard deviation of 20 blank measurements and $m$ is the slope of the calibration curve. The limit of quantification was calculated as $10 \mathrm{~s} / \mathrm{m}$. The blank was a $0.2 \% \mathrm{HNO}_{3}$ solution.

The instrumental precision was evaluated by measuring 20 times the absorbance signals in the same digested olive fruit sample under the established instrumental conditions. For the evaluation of the precision of the analytical method, readings of 20 different digested solutions of the same olive fruit sample were performed for all of the analytes.

The accuracy of the method was determined by the standard addition analysis. Four different concentrations (between 0.5 and $2.0 \mu \mathrm{g} / \mathrm{L}$ for $\mathrm{Cd}$, between 2.5 and $20 \mu \mathrm{g} / \mathrm{L}$ for $\mathrm{Cu}, \mathrm{Cr}, \mathrm{Fe}$, and $\mathrm{Pb}$, and between 5.0 and $50 \mu \mathrm{g} / \mathrm{L}$ for $\mathrm{Al}$ and $\mathrm{Ni}$ ) of metal standard solutions were added to the olive fruit samples (six replicates for each concentration). The spiked samples were submitted to the overall procedure, the metals quantified by the established conditions, and the respective recoveries calculated.

The evaluation of putative interferences of the matrix was carried out in a simulated matrix prepared by mixing the principal organic and inorganic constituents of olive fruits, which are listed in Table 2 (17). Four concentrations of each metal were added to several aliquots of this simulated matrix (between 0.5 and $2.0 \mu \mathrm{g} / \mathrm{L}$ for $\mathrm{Cd}$, between 2.5 and $20.0 \mu \mathrm{g} / \mathrm{L}$ for $\mathrm{Cu}, \mathrm{Cr}$, and $\mathrm{Fe}$, and between 5.0 and $50.0 \mu \mathrm{g} / \mathrm{L}$ for $\mathrm{Al}, \mathrm{Pb}$, and $\mathrm{Ni}$ ). These spiked matrices were submitted to the overall procedure, the metals were measured in the digested solutions against the respective standards, and the deviations of the expected values were determined.

Application of the Validated Method. Field Trials. The trials were carried out in an olive grove located near Mirandela, Trás-os-Montes, in northeastern Portugal. The production and protection followed the Integrated Production (18) and Protection Management (8) guidelines. The orchard was subdivided in four plots, three of them for application of three different copper preparations and one as control. Treatments were carried out on October 15, 2003, with a motorized sprayer (Tomix P12, APS121, Tomix - Indústria de Equipamentos Agrícolas e Industriais, Lda., Torres Vedras, Portugal). The commercial formulations were Bordeaux mixture Valles $\left[\mathrm{CuSO}_{4}+\mathrm{Ca}(\mathrm{OH})_{2}\right.$ with $20 \% \mathrm{Cu}$; 


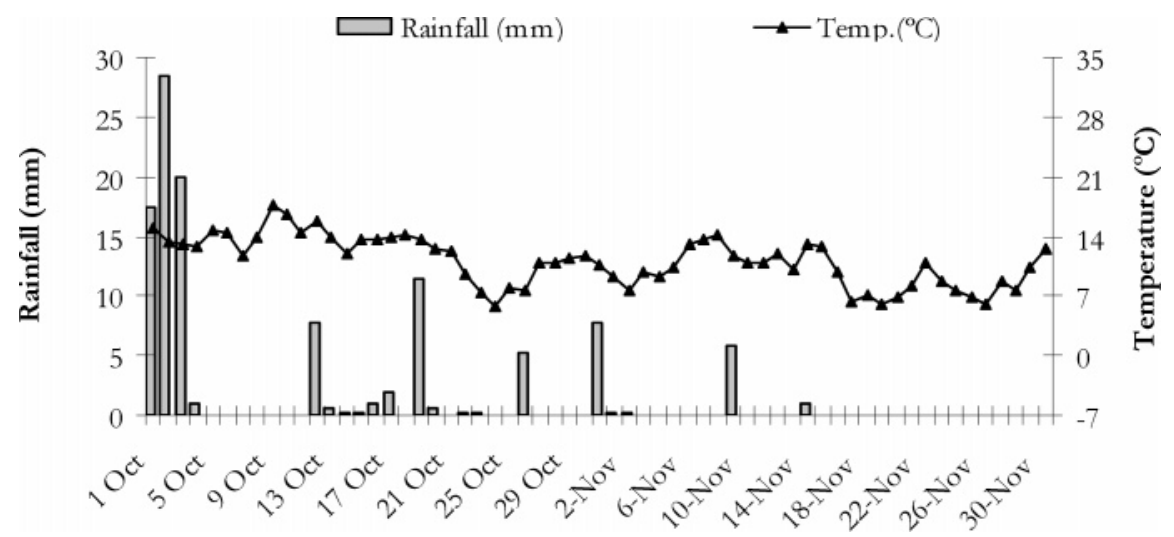

Figure 1. Climatic conditions during the experiment.

Valles, Portugal], Kocide DF $\left[\mathrm{Cu}(\mathrm{OH})_{2}\right.$ with $40 \% \mathrm{Cu}$; Agroquisa, Portugal], and Curenox $50\left[\mathrm{Cu}(\mathrm{OCl})_{2}\right.$ with $50 \% \mathrm{Cu}$; Valles, Portugal], and they were used at the concentrations recommended by the manufacturer $(15,5$, and $5 \mathrm{~g} / \mathrm{L}$, corresponding to $3.0,2.0$, and $2.5 \mathrm{~g} / \mathrm{L}$ of copper, respectively). The control plot was sprayed with water. The weather conditions were continuously recorded with an automatic weather station (Figure 1). Sampling started $4 \mathrm{~h}$ after treatment and was repeated after $8,13,28$, and 44 days. In each sampling and per treatment, five trees were randomly selected in the middle of each plot, and 60 healthy olive fruits per tree were collected around the whole perimeter of each tree at the operator height. The samples were stored in plastic bags at $-20{ }^{\circ} \mathrm{C}$ until metal analysis.

Statistical Analysis. In the olive samples the measurements were carried out in duplicate, for each sample. The results are shown as mean values and standard error for all of the sampling periods and treatments. The differences in copper concentration for the different treatments were analyzed using the analysis of variance one-way (ANOVA) followed by a Tukey test with $\alpha=0.05$. This treatment was carried out using the SAS v. 9.1.3 program.

\section{RESULTS AND DISCUSSION}

The quantification of trace elements in biological samples generally implies the simplification of the matrix to obtain the effective dissolution of the samples. The edible portion of olive fruit is mainly constituted by fatty matter (during the sampling period the fatty matter of cv. Cobrançosa olives was between 33 and $54 \%$ in the dry fruits), which constitutes a difficulty in the simplification of the matrix for further quantification of the metals. The principal steps of the sample simplification consisted of the dehydration in an oven at $60 \pm 2{ }^{\circ} \mathrm{C}$ for several days, pulverization of the dried product in a Teflon container, and addition of an oxidant mixture $\left(\mathrm{HNO}_{3}+\mathrm{HCl}\right.$ and $\left.\mathrm{H}_{2} \mathrm{O}_{2}\right)$ to mineralize the sample. The metals were measured in the digested solutions. An ashing digestion was adopted by others for the quantification of iron and manganese in table olives (16). To avoid losses of some volatile metals herein included such as cadmium and lead, we adopted a wet acid digestion method in a closed vessel as a pretreatment procedure. To verify the possible interference of silicates present in the olive matrix on the quantification of the elements under study, a wet digestion procedure including a preliminary dissolution step with $\mathrm{HF}$ and $\mathrm{HNO}_{3}$ was also carried out. Six aliquots of olive sample were dissolved in $\mathrm{HF}$ and $\mathrm{HNO}_{3}$, and the remaining residue was digested as previously described, that is, with $\mathrm{HNO}_{3}+\mathrm{HCl}$ and $\mathrm{H}_{2} \mathrm{O}_{2}$. In parallel, six aliquots of the same olive sample were digested only with $\mathrm{HNO}_{3}+\mathrm{HCl}$ and $\mathrm{H}_{2} \mathrm{O}_{2}$. The metals were quantified in all of the resulting digested solutions, and the mean values obtained for the digestion procedure including HF dissolution and for the digestion procedure performed with only the oxidant solution are presented in Table 3. As can be
Table 3. Deviations from Expected Values for the Metals Obtained after Wet Digestion without and with HF (Levels Are Expressed as Mean Values of Six Independent Assays)

\begin{tabular}{lccc}
\hline \multicolumn{1}{c}{ metal } & procedure $^{a}$ & procedure B $^{b}$ & RSD (\%) \\
\hline $\mathrm{Cu}(\mu \mathrm{g} / \mathrm{g})$ & 0.88 & 0.94 & +6.4 \\
$\mathrm{Al}(\mu \mathrm{g} / \mathrm{g})$ & 2.37 & 2.38 & +0.5 \\
$\mathrm{Cd}(\mu \mathrm{g} / \mathrm{kg})$ & 0.98 & 1.08 & +3.0 \\
$\mathrm{Cr}(\mu \mathrm{g} / \mathrm{kg})$ & 40.8 & 41.7 & +2.2 \\
$\mathrm{Fe}(\mu \mathrm{g} / \mathrm{g})$ & 3.36 & 3.38 & +0.6 \\
$\mathrm{~Pb}(\mu \mathrm{g} / \mathrm{kg})$ & 19.2 & 20.0 & +4.0 \\
$\mathrm{Ni}(\mu \mathrm{g} / \mathrm{kg})$ & 17.0 & 16.5 & -3.0
\end{tabular}

a Procedure A: wet digestion with $\mathrm{HNO}_{3}+\mathrm{HCl}+\mathrm{H}_{2} \mathrm{O}_{2} \cdot{ }^{b}$ Procedure $\mathrm{B}$ : wet digestion with $\mathrm{HF}+\mathrm{HNO}_{3}$ followed by $\mathrm{HNO}_{3}+\mathrm{HCl}+\mathrm{H}_{2} \mathrm{O}_{2}$.

Table 4. Performance of the Method

\begin{tabular}{|c|c|c|c|c|c|c|c|}
\hline & \multicolumn{2}{|c|}{ precision (CV \%) } & \multirow[b]{2}{*}{$\begin{array}{l}\text { linearity } \\
(\mu \mathrm{g} / \mathrm{L})\end{array}$} & \multicolumn{2}{|c|}{ detection limit } & \multicolumn{2}{|c|}{ quantification limit } \\
\hline & instrumental & $\begin{array}{l}\text { analytical } \\
\text { procedure }\end{array}$ & & $\mu \mathrm{g} / \mathrm{L}$ & $\mathrm{ng} / \mathrm{g}$ & $\mu \mathrm{g} / \mathrm{L}$ & $\mathrm{ng} / \mathrm{g}$ \\
\hline $\mathrm{Cu}$ & 0.7 & 3.2 & $0.19-20.0$ & 0.19 & 3.80 & 0.63 & 12.6 \\
\hline $\mathrm{Al}$ & 3.0 & 12.0 & $1.11-50.0$ & 1.11 & 22.2 & 3.70 & 74.0 \\
\hline $\mathrm{Cd}$ & 1.4 & 7.1 & $0.02-2.0$ & 0.02 & 0.40 & 0.07 & 1.34 \\
\hline $\mathrm{Cr}$ & 2.2 & 4.5 & $0.15-20.0$ & 0.15 & 3.00 & 0.50 & 10.0 \\
\hline $\mathrm{Fe}$ & 1.4 & 5.1 & $0.80-20.0$ & 0.80 & 16.0 & 2.67 & 53.4 \\
\hline $\mathrm{Pb}$ & 5.4 & 9.2 & $0.35-50.0$ & 0.35 & 7.00 & 1.17 & 23.4 \\
\hline $\mathrm{Ni}$ & 6.3 & 8.0 & $0.60-50.0$ & 0.60 & 12.0 & 2.00 & 40.0 \\
\hline
\end{tabular}

observed, no differences were found in the content of all the elements under study. Thus, the simplified method of digestion performed with the oxidant mixture $\left(\mathrm{HNO}_{3}+\mathrm{HCl}\right.$ and $\left.\mathrm{H}_{2} \mathrm{O}_{2}\right)$ was adopted.

The precision, evaluated both for the instrumental and the analytical procedure, was $<10 \%$ for all of the analyzed metals, except for $\mathrm{Al}$ for which it was $12 \%$ as shown in Table 4.

Because there are no certified reference materials for heavy metals in olive fruits, the accuracy studies were performed by the standard additions method, submitting the spiked samples to the overall procedure and measuring the metals in the samples digested as described. This study was carried out with four different concentrations of each metal, and the recoveries obtained were always $>90 \%$ for all of the metals, as shown in Table 5. The obtained results showed that there was no contamination or loss during the pretreatment procedure for all of the analyzed metals.

On the basis of $0.5 \mathrm{~g}$ of dried sample in a final volume of 10 $\mathrm{mL}$, the limits of detection were $3.8,22.2,0.40,3.0,16.0,7.0$, and $12.0 \mathrm{ng} / \mathrm{g}$ and the limits of quantification were 12.6, 74.0, 1.34, 10.0, 53.4, 23.4, and $40.0 \mathrm{ng} / \mathrm{g}$ for $\mathrm{Cu}, \mathrm{Al}, \mathrm{Cd}, \mathrm{Cr}, \mathrm{Fe}$, $\mathrm{Pb}$, and $\mathrm{Ni}$, respectively (Table 4). 
Table 5. Accuracy Study As Determined by the Standard Additions Method

\begin{tabular}{|c|c|c|c|c|c|}
\hline \multirow[b]{2}{*}{ metal } & \multicolumn{5}{|c|}{ concn $\mu \mathrm{g} / \mathrm{L}(n=6)$} \\
\hline & 0.5 & & & 1.5 & 2.0 \\
\hline \multirow[t]{2}{*}{$\mathrm{Cd}$} & $95 \pm 3$ & & & $94 \pm 2$ & $92 \pm 2$ \\
\hline & \multicolumn{5}{|c|}{ concn $\mu \mathrm{g} / \mathrm{L}(n=6)$} \\
\hline metal & 2.5 & 5.0 & 10.0 & 20.0 & 50.0 \\
\hline $\begin{array}{l}\mathrm{Cu} \\
\mathrm{Al} \\
\mathrm{Cr} \\
\mathrm{Fe} \\
\mathrm{Pb} \\
\mathrm{Ni}\end{array}$ & $\begin{array}{l}94 \pm 2 \\
96 \pm 2 \\
94 \pm 2 \\
94 \pm 3\end{array}$ & $\begin{array}{l}94 \pm 4 \\
95 \pm 4 \\
95 \pm 4 \\
93 \pm 3 \\
96 \pm 2 \\
92 \pm 2\end{array}$ & $\begin{array}{l}95 \pm 3 \\
93 \pm 3 \\
95 \pm 3 \\
92 \pm 2 \\
96 \pm 2 \\
93 \pm 2\end{array}$ & $\begin{array}{l}98 \pm 2 \\
92 \pm 2 \\
97 \pm 3 \\
95 \pm 4 \\
96 \pm 3 \\
94 \pm 3\end{array}$ & $95 \pm 3$ \\
\hline
\end{tabular}

The maximum residue level (MRL) established by legislation is $20 \mu \mathrm{g} / \mathrm{g}$ of wet weight in olive fruits for $\mathrm{Cu}$ after application of fungicides containing this element. Considering $57 \%$ the medium moisture of cv. Cobrançosa olives in the period of sampling, the MRL corresponds to $46.4 \mu \mathrm{g} / \mathrm{g}$ of dry weight. The limit of quantification of the present method for copper $(12.6 \mathrm{ng} / \mathrm{g})$ is thus able to control residues of the element well bellow the MRL established by legislation $(19,20)$.

Referring to the other metals, there are no specific limits for this fruit, although the European Community establishes $0.2 \mu \mathrm{g} / \mathrm{g}$ of wet weight $(0.46 \mu \mathrm{g} / \mathrm{g}$ of dry weight $)$ for $\mathrm{Pb}$ and $\mathrm{Cd}$ in berries and other small fruits (20). Also, for these metals the limit of quantification of our method enables the control of their contents.

The results of the interferences study are summarized in Table 6. As can be observed, deviations from the expected values are always $<6 \%$ for all of the metals and for all of the added metal concentrations. From this study we can conclude that there was no noticeable interference of the principal constituents on the analyzed metals.

The present method was applied to monitor the copper levels of olive fruit collected from trees pulverized with copper fungicides as well as other metal contaminants with toxicological, nutritional, and stability concerns.

Copper was measured in the olive fruits collected at $4 \mathrm{~h}$ and $8,13,28$, and 44 days after pulverization of the trees with three copper formulations available on the market, which were
Table 6. Deviations from Expected Values for the Metals Obtained in the Matrix Interference Study

\begin{tabular}{|c|c|c|c|}
\hline metal & $\begin{array}{c}\text { concn added } \\
\left(\mu \mathrm{g} \mathrm{L}^{-1}\right)\end{array}$ & $\begin{array}{l}\text { concn }{ }^{a} \text { found } \\
\left(\mu \mathrm{g} \mathrm{L}^{-1}\right)\end{array}$ & $\begin{array}{c}\text { deviation from } \\
\text { expected values }(\%)\end{array}$ \\
\hline $\mathrm{Cu}$ & $\begin{array}{r}2.5 \\
5.0 \\
10.0 \\
20.0\end{array}$ & $\begin{array}{r}2.4 \\
4.8 \\
9.6 \\
19.4\end{array}$ & $\begin{array}{l}3.1 \\
2.0 \\
2.9 \\
1.6\end{array}$ \\
\hline $\mathrm{Al}$ & $\begin{array}{r}5.0 \\
10.0 \\
20.0 \\
50.0\end{array}$ & $\begin{array}{r}4.7 \\
9.6 \\
18.6 \\
46.0\end{array}$ & $\begin{array}{l}3.1 \\
2.9 \\
2.4 \\
2.2\end{array}$ \\
\hline $\mathrm{Cd}$ & $\begin{array}{l}0.50 \\
1.00 \\
1.50 \\
2.00\end{array}$ & $\begin{array}{l}0.48 \\
0.96 \\
1.44 \\
1.94\end{array}$ & $\begin{array}{l}2.70 \\
1.80 \\
1.00 \\
1.40\end{array}$ \\
\hline $\mathrm{Cr}$ & $\begin{array}{r}2.5 \\
5.0 \\
10.0 \\
20.0\end{array}$ & $\begin{array}{r}2.4 \\
4.9 \\
9.6 \\
19.2\end{array}$ & $\begin{array}{l}5.0 \\
1.5 \\
1.0 \\
1.9\end{array}$ \\
\hline $\mathrm{Fe}$ & $\begin{array}{r}2.5 \\
5.0 \\
10.0 \\
20.0\end{array}$ & $\begin{array}{r}2.4 \\
4.6 \\
9.4 \\
18.6\end{array}$ & $\begin{array}{l}6.0 \\
2.0 \\
4.0 \\
4.0\end{array}$ \\
\hline $\mathrm{Pb}$ & $\begin{array}{r}5.0 \\
10.0 \\
20.0 \\
50.0\end{array}$ & $\begin{array}{r}4.8 \\
9.3 \\
19.4 \\
48.5\end{array}$ & $\begin{array}{l}2.3 \\
3.1 \\
3.3 \\
1.6\end{array}$ \\
\hline $\mathrm{Ni}$ & $\begin{array}{r}5.0 \\
10.0 \\
20.0 \\
50.0\end{array}$ & $\begin{array}{r}4.6 \\
9.1 \\
18.8 \\
47.0\end{array}$ & $\begin{array}{l}1.6 \\
1.6 \\
3.6 \\
3.3\end{array}$ \\
\hline
\end{tabular}

${ }^{a}$ Results are expressed as mean values of six assays.

constituted by different compounds of the element. When prepared according to the manufacturers' recommendations, the final water suspensions for pulverization contained 3.0, 2.0, and $2.5 \mathrm{~g}$ of copper per liter, for $\mathrm{CuSO}_{4}+\mathrm{Ca}(\mathrm{OH})_{2}(20 \% \mathrm{Cu})$, $\mathrm{Cu}(\mathrm{OH})_{2}(40 \% \mathrm{Cu})$, and $\mathrm{Cu}(\mathrm{OCl})_{2}(50 \% \mathrm{Cu})$, respectively.

The mean copper concentrations found in the olive fruits collected at different times after pulverization are presented in Figure 2 and expressed in micrograms per gram of dry weight. The copper contents in the control sample remained constant during the 44 days of the experiment, ranging from 7.6 to 9.2

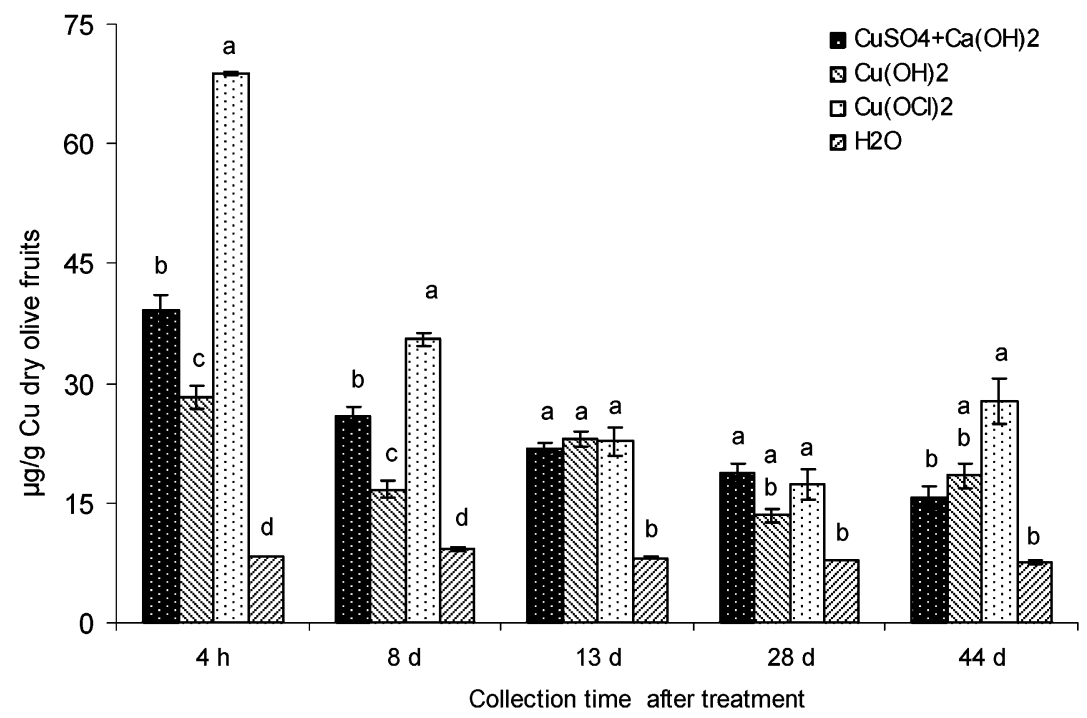

Figure 2. Content of $\mathrm{Cu}$ (mean $\pm \mathrm{SEM}$ ) in olive fruits $(\mu \mathrm{g} / \mathrm{g}$ of dry olives) $4 \mathrm{~h}$ and $8,13,28$, and 44 days after each fungicide treatment. Different letters indicate significant differences $(p<0.05)$ between treatments in each time. 
Table 7. Curve Equation Obtained by the Relationship Established between Time of Olive Fruit Collection and Copper Concentrationa

\begin{tabular}{llrr}
\hline \multicolumn{1}{c}{ pesticide } & \multicolumn{1}{c}{ equation } & $r^{2}$ & \multicolumn{1}{c}{$t_{1 / 2}$} \\
\hline $\mathrm{CuSO}_{4}+\mathrm{Cu}(\mathrm{OH})_{2}$ & $y=0.0186 x^{2}-1.2879 x+37.197$ & 0.9387 & 18.8 \\
$\mathrm{Cu}(\mathrm{OH})_{2}$ & $y=0.0193 x^{2}-1.169 x+30.482$ & 0.9629 & 19.3 \\
$\mathrm{Cu}(\mathrm{OCl})_{2}$ & $y=0.0694 x^{2}-3.8638 x+65.311$ & 0.9525 & 9.7
\end{tabular}

${ }^{a} r^{2}$, coefficient of determination and half-life $\left(t_{1 / 2}\right)$ time of disappearance of copper in olive fruits.

$\mu \mathrm{g} / \mathrm{g}$. Four hours after the fungicide application, all of the copper formulations originated significant contamination of the olive fruits, about 5 times the copper contents for the formulation containing $20 \% \mathrm{Cu}, 3$ times for the formulation containing $40 \%$ $\mathrm{Cu}$, and 8 times for the formulation containing $50 \% \mathrm{Cu}$, when compared with the control samples. The levels found were 39.1, $28.2,68.8$, and $8.3 \mu \mathrm{g} / \mathrm{g}$ of dry weight for $\mathrm{CuSO}_{4}+\mathrm{Ca}(\mathrm{OH})_{2}$ $(20 \% \mathrm{Cu}), \mathrm{Cu}(\mathrm{OH})_{2}(40 \% \mathrm{Cu}), \mathrm{Cu}(\mathrm{OCl})_{2}(50 \% \mathrm{Cu})$, and water, respectively. Only for the first collection time $(4 \mathrm{~h}$ after pulverization) did the olive fruits treated with $\mathrm{Cu}(\mathrm{OCl})_{2}$ present copper residues higher than the allowed MRL $(46.4 \mu \mathrm{g} / \mathrm{g}$ of dry weight) (18). During the other collection times the residue contents were progressively lower for all of the different treatments.

Despite the higher concentration of copper in the $\mathrm{CuSO}_{4}+$ $\mathrm{Ca}(\mathrm{OH})_{2}(20 \% \mathrm{Cu})$ suspension $(3.0 \mathrm{~g} / \mathrm{L})$, the copper residues
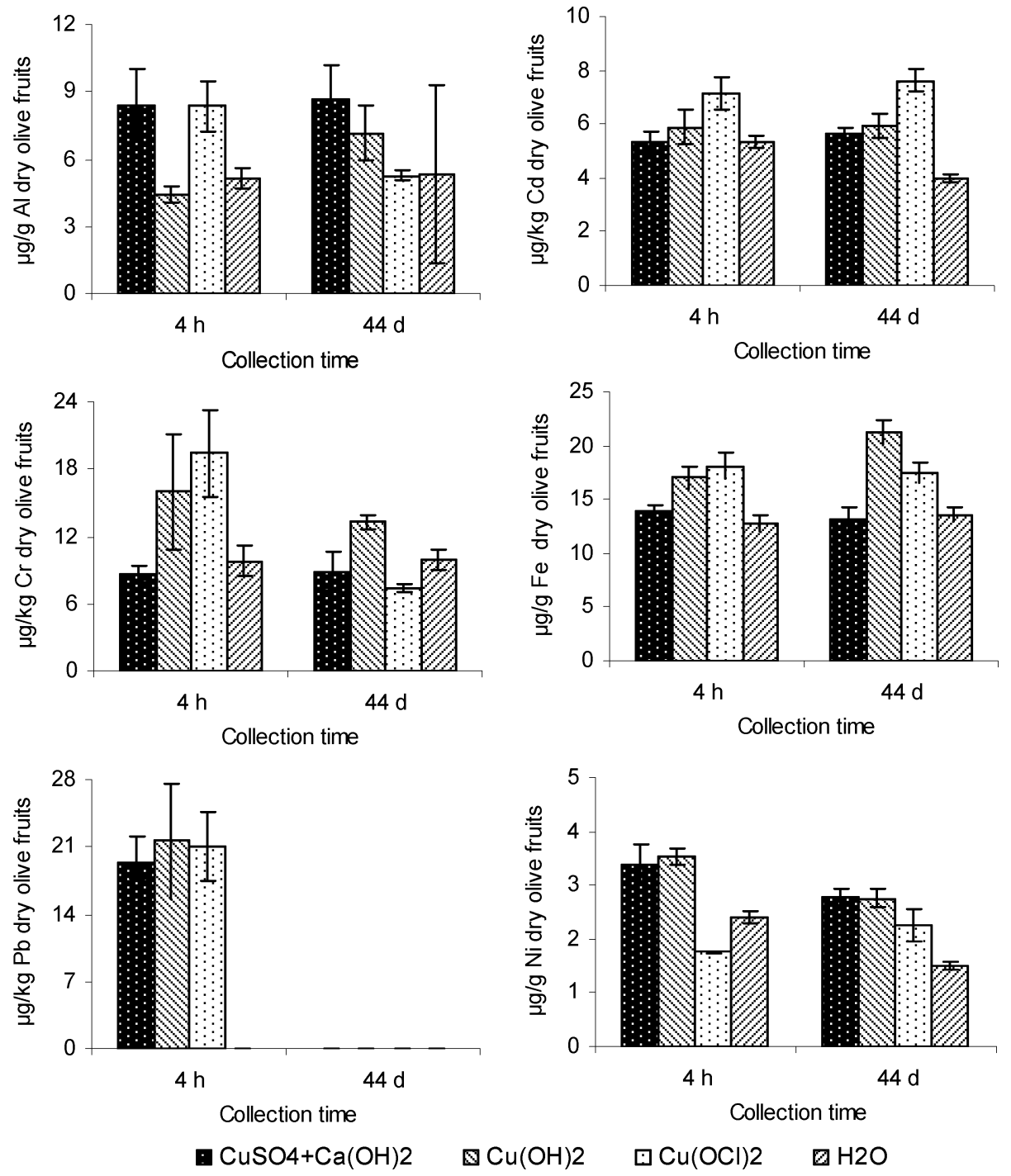

were significantly higher in the olive fruits treated with the $\mathrm{Cu}(\mathrm{OCl})_{2}(50 \% \mathrm{Cu})$ suspension $(2.5 \mathrm{~g} / \mathrm{L})$ in the two first collection times, compared with the olives of the other treatments and water.

At day 44 after pulverization, only olive fruits collected from the trees treated with $\mathrm{Cu}(\mathrm{OCl})_{2}(50 \% \mathrm{Cu})$ presented copper residue contents significantly higher than those of the water treatment.

Good correlations were obtained between collection time and copper concentration on olives fruits, as shown by the high coefficients of determination that were $0.9387,0.9629$, and 0.9525 for $\mathrm{CuSO}_{4}+\mathrm{Ca}(\mathrm{OH})_{2}(20 \% \mathrm{Cu}), \mathrm{Cu}(\mathrm{OH})_{2}(40 \% \mathrm{Cu})$, and $\mathrm{Cu}(\mathrm{OCl})_{2}(50 \% \mathrm{Cu})$, respectively (Table 7). The data obtained demonstrated that the rate of disappearance of copper in olive fruits depends on the copper formulation. In this trial we observed a more marked decay of copper for the $\mathrm{Cu}(\mathrm{OCl})_{2}$ formulation, with a $t_{1 / 2}$ of 9.7 days and a similar decay for the $\mathrm{CuSO}_{4}+\mathrm{Ca}(\mathrm{OH})_{2}(20 \% \mathrm{Cu})$ and $\mathrm{Cu}(\mathrm{OH})_{2}(40 \% \mathrm{Cu})$ formulations with $t_{1 / 2}$ values of 18.8 and 19.3 days, respectively. Although the residues are higher after 44 days, the decay is more effective for this formulation.

Taking the legislated copper contents in olive fruits $(46.4 \mu \mathrm{g} / \mathrm{g}$ of dry weight) and the recommended withdrawal period for harvesting (7 days) into account, we can conclude that all of the fungicide formulations proportionate acceptable copper residue levels.
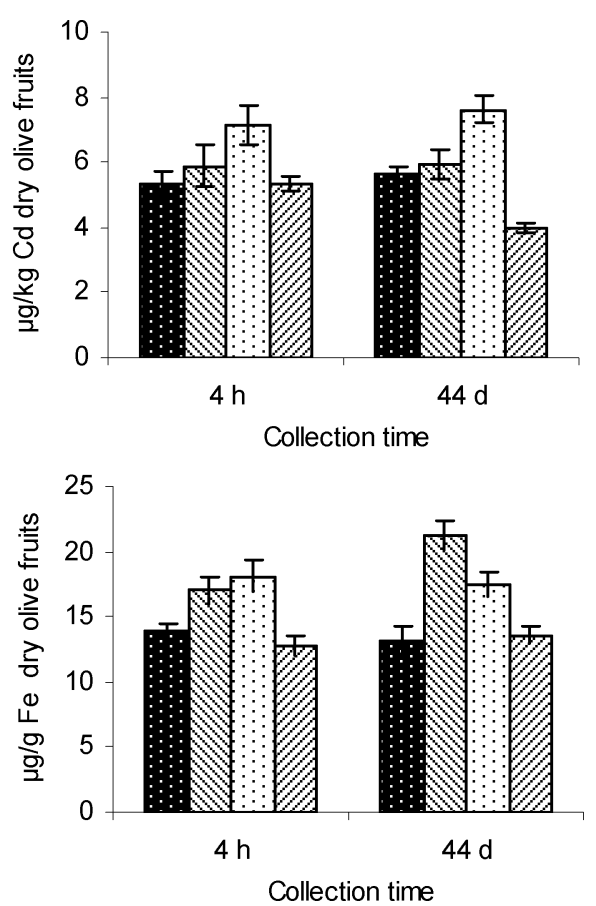

Figure 3. Metal contents (mean \pm SEM) in olive fruits $4 \mathrm{~h}$ and 44 days after fungicide treatments. 
Besides the concentration of the metal in the applied fungicide and the rainfall after pulverization, other factors can contribute to the copper contents of the olives, namely, the $\mathrm{pH}$ of the applied product, which was 7.44, 8.18, and 6.86, for $\mathrm{CuSO}_{4}+$ $\mathrm{Ca}(\mathrm{OH})_{2}(20 \% \mathrm{Cu}), \mathrm{Cu}(\mathrm{OH})_{2}(40 \% \mathrm{Cu})$, and $\mathrm{Cu}(\mathrm{OCl})_{2}(50 \%$ $\mathrm{Cu}$ ), respectively. Although not dramatically different, the acidic $\mathrm{pH}$ of the $\mathrm{Cu}(\mathrm{OCl})_{2}(50 \% \mathrm{Cu})$ suspension can facilitate the adherence of the salt on the olive fruits, partially explaining the higher residues of copper even though this suspension was not the most concentrated in the element. With regard to the influence of rainfall, as we can see in Figure 1 the period after the pulverization was essentially dry, although some rain occurred between the days of the harvesting. As this climatic condition similarly affected all of the trees, we can assume that the higher level of copper present in the olive fruits treated with the $\mathrm{Cu}(\mathrm{OCl})_{2}(50 \% \mathrm{Cu})$ formulation is due to its composition.

As already confirmed by other authors (2), the presence of transition metals in olive oils can be determinant in their organoleptic and quality characteristics, because copper is a very efficient catalyst of the olive oil oxidation as evaluated by the Rancimat test. As these olive fruits are also used to make oil, it is very important that the copper contents are within allowable levels to prevent the undesirable phenomenon of oxidation. Such a control can be achieved by this validated method.

The contents of aluminum, cadmium, chromium, lead, and nickel were also quantified in the olive fruits from the trees submitted to the different treatments and for the several collection times. The data obtained for the first $(4 \mathrm{~h})$ and last (44 days) collection times after treatment are presented in Figure 3. Only for lead were similar profiles in the decay of the metal residues in the fruit samples found, which were identical for the first collection time for the three treatments (between 21.0 and $26.4 \mu \mathrm{g} / \mathrm{kg}$ ), and were all reduced to values lower than the limit of detection in the last collection time. Olive fruits from water treatment presented lead levels lower than the limit of detection, for both the first and last collection times. For this metal it seems reasonable to conclude that its presence in the first collection time after pulverization of the copper formulations is a consequence of contamination. For the other metals, although presenting some aleatory character, the results were similar for all treatments and control and for all of the collection times. We can thus conclude that the contents of these metals in the olive fruit are mainly of endogenous origin.

\section{LITERATURE CITED}

(1) Kiritsakis, A. K. Olive Oil from the Tree to the Table; Food and Nutrition Press: Trumbull, CT, 1998; 348 pp.

(2) De Leonardis, A.; Macciola, V. Catalytic effect of the $\mathrm{Cu}(\mathrm{II})-$

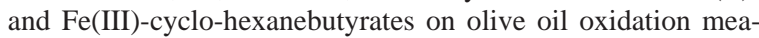
sured by Rancimat. Eur. J. Lipid Sci. Technol. 2002, 104, 156160.

(3) De Andrés, F. Enfermidades y Plagas del Olivo, 2nd ed.; Riquelme y Vargas Ediciones: Jaén, Spain, 1991; 646 pp.

(4) Trapero, A.; Blanco, M. A. Enfermedades. In El Cultivo del Olivo; Barranco, D., Fernández-Escobar, R., Rallo, L., Eds.; Junta de Andalucía-MundiPrensa: Madrid, Spain, 1999; pp 479-532.

(5) Gouveia, M. E.; Coelho, V.; Bento, A. O "olho de pavão" (Spilocaea oleagina) na região de Mirandela. Distribuição, incidência, severidade e densidade do inóculo. Rev. Cienc. Agrar. 1998, 21, 287-294.
(6) Agosteo, G. E.; Magnato, G.; Cacciola, S.; Frisulli, S. Characterization of the causal agent of olive anthracnose in Southern Italy. Acta Hortic. 2002, 586, 713-716.

(7) http://www.dgpc.min-agricultura.pt/fitofarmaceuticos/guia. htm.

(8) Gomes, H. B.; Cavaco, M. Protecção Integrada da OliveiraLista dos produtos fitofarmacêuticos, níveis económicos de ataque; Ministério da Agricultura, Desenvolvimento Rural e Pescas-Direcção Geral de Protecção das Culturas: Oeiras, Portugal, 2003; 55 pp.

(9) Council Regulation (EEC) 2092/91 of 24 June 1991.

(10) La Pera, L.; Lo Coco, F.; Mavrogeni, E.; Giuffrida; D.; Dugo, G. Determination of copper(II), lead(II), cadmium(II) and zinc(II) in virgin olive oils produced in Sicily and Apulia by derivative potenciometric stripping analysis. Ital. J. Food Sci. 2002, 14, 389-399.

(11) Lo Coco, F.; Monotti, P.; Rizzotti, S.; Ceccon, L. Determination of lead in oil products by derivative potentiometric stripping analysis. Anal. Chim. Acta 1999, 386, 41-46.

(12) La Pera, L.; Lo Curto, S.; Visco, A.; La Torre, L.; Dugo, G. Derivative potenciometric stripping analysis (dPSA) used for the determination of cadmium, copper, lead, and zinc in Sicilian olive oils. J. Agric. Food Chem. 2002, 50, 3090-3093.

(13) Galeno Díaz, T.; Guiberteau, A.; López Soto, M. D.; Ortiz, J. M. Spectrophotometric and adsorptive stripping square wave voltammetric determination of iron in olive oils, as complex with 5,5-dimethylcyclohexane-1,2,3-trione 1,2-dioxime 3-thiosemicarbazone (DCDT). J. Agric. Food Chem. 2003, 51, 3743-3747.

(14) Lo Coco, F.; Ceccon, K.; Ciraolo, L.; Novelli, V. Determination of cadmium(II) and zinc(II) in olive oils by derivative potentiometric stripping analysis. Food Control 2003, 14, 55-59.

(15) Galeno Díaz, T.; Guiberteau, A.; López Soto, M. D.; Ortiz, J. M. Determination of copper with 5,5-dimethylcyclohexane-1,2,3trione 1,2-dioxime 3-thiosemicarbazone in olive oils by adsorptive stripping square wave voltammetry. Food Chem. 2006, 96, $156-162$.

(16) García, P.; Romero, C.; Brenes, M.; Garrido, A. Validation of a method for the analysis of iron and manganese in table olives by flame atomic absorption spectrometry. J. Agric. Food Chem. 2002, 50, 3654-3659.

(17) Holland, B.; Welch, A. A.; Unwin, I. D.; Buss, D. H.; Paul, A. A.; Southgate, D. A. T. The Composition of Foods, 5th rev. extended ed.; McCance and Widdowson's, The Royal Society of Chemistry, Cambridge, and the Ministry of Agriculture, Fisheries and Food: London, U.K., 1998.

(18) Soveral-Dias, J. C.; Jordão, P. V.; Marcelo, M. E.; Calouro, F.; Antunes, A. F.; Cordeiro, A. M.; Santos, L. S.; Morais, N. C. Produção Integrada da oliveira. Fertilização e outras Práticas Culturais; MADRP, INIA, DGPC, DGDR: Lisboa, Portugal, 2000.

(19) Portaria 649/96 de 12 de Novembro. Diario Republica-I Ser. B (Portugal) 1996.

(20) Commission Directive 2001/22/EC of 8 March 2001 laying down the sampling methods and the methods of analysis for the official control of the levels of lead, cadmium, mercury and 3-MCPD in foodstuffs. Off. J. Eur. Communities 2001, L 07, 0014-0021.

Received for review March 30, 2006. Accepted April 4, 2006. 